\title{
The Educational Regenerationism in Spain
}

\author{
Rafael Salinas, Isabel Alvarez* \\ Department of Systematic and Social Pedagogy, Autonomous University of Barcelona, Spain
}

Received January 5, 2021; Revised February 7, 2021; Accepted March 6, 2021

\section{Cite This Paper in the following Citation Styles}

(a): [1] Rafael Salinas, Isabel Alvarez, "The Educational Regenerationism in Spain," Universal Journal of Educational Research, Vol. 9, No. 3, pp. 540-548, 2021. DOI: 10.13189/ujer.2021.090313.

(b): Rafael Salinas, Isabel Alvarez (2021). The Educational Regenerationism in Spain. Universal Journal of Educational Research, 9(3), 540-548. DOI: 10.13189/ujer.2021.090313.

Copyright $\bigcirc 2021$ by authors, all rights reserved. Authors agree that this article remains permanently open access under the terms of the Creative Commons Attribution License 4.0 International License

\begin{abstract}
The aim of this paper is to show how the Spanish Pedagogical Conferences between 1882 and 1908 influenced the promotion of innovative teaching at that time. Pedagogical Conferences were the only forum through which both rural and urban schoolteachers were able to implement new educational ideas. Books were not available, so at that time schoolteachers would write their own textbooks to use in their schools. We will focus on one of these teachers, and through his eyes we will show how these conferences helped tackle illiteracy and elementary school dropout. Furthermore, we will highlight this teacher's particular contributions to the Teacher Training, through the work of the Free Teaching Institute, in which he directed a programme of in-depth educational reform, focusing on primary schools, as the foundation of a child's education, but also including the development of the National Pedagogical Museum project. In addition, we include the dissemination of knowledge through school libraries in places and circumstances where no such resources had been available hitherto. To sum up, the Spanish Pedagogical Conferences highlight the vision and initiatives that our infectious and energetic author brought to the development of professional teaching networks, whose ultimate goal was to promote equal and free education.
\end{abstract}

Keywords Pedagogical Congresses, Innovation, Macho Moreno

\section{Introduction}

The development of education in Spain in the $19^{\text {th }}$ century saw a turning point with the creation of The Free
Institution of Education (FIE), 1876, and The National Pedagogical Museum, 1882. While the FIE is constituted as a response to the coercion of academic freedom represented by the Orovio sentence, the Museum is the organ whereby all the advances in primary education have been already verified in other countries and introduced in Spain, in collaboration with the mission of the Normal Schools of higher education. The FIE affects educational change, while the Museum is the driver of transformation.

The tedious educational structure starts changing with the new pedagogical concerns. From this moment onwards, civil society promotes educational debate in the primary and secondary sectors, through professional encounters at a national and provincial level.

The creation of the Promotion of the Arts (1847) aims to make education available to the lower classes, the working class, coincides with the emergence of new institutions in the development of pedagogical reform and convenes the first National Pedagogical Conference (1882), with the support of the incipient National Teachers' Association, subsequent to which further encounters will be called, always under the responsibility of civil bodies. The government sets up a major educational event in 1910. Potentially the event will offer the greatest opportunity for free debate concerning the educational structure of the country, which for different reasons (government instability, pressure from religious education, corporate immaturity) does not actually take place.

From the outset, Juan Macho Moreno (1848-1912), participates actively in such events, and contributes, in each one that he attends, the general outlook of rank-and-file teachers. His position as school-teacher does not prevent him from expounding the manifest truth of the teaching profession as a whole, and nor does his high rank 
discourage him from pursuing the struggle for the right to a free, high-quality education with all the guarantees.

\section{Congresses and National Boards}

In the second half of the $19^{\text {th }}$ century and the start of the $20^{\text {th }}$, teachers essentially had access to two ways of acquiring information about educational innovation: in the first place, by reading books and magazines; secondly, by sharing experiences and opinions at Congresses, conferences, exhibitions and international exchanges [1]. The aim of this paper will be to examine in detail how innovation on behalf of teachers comes about, both in Pedagogical Congresses and, specifically, through the work of Juan Macho Moreno.

From the beginning, Macho Moreno participates in the Teaching Profession movements and in meetings organised for teachers. We have ascertained that during his teaching career the following events are held: The National Pedagogical Congress 1882 (Madrid), The Congress of the Society for Public Education and Social Improvement 1890 (Madrid), The National Pedagogical Congress 1903 (Albacete), The National Pedagogical Congress 1907 (Zaragoza), The Primary Education Congress 1909 (Santiago de Compostela), The National Schools Congress 1909 (Valencia) and The Primary Education Congress 1911 (Barcelona) [2].

$\mathrm{He}$ is a participant from the first National Pedagogical Congress (1882) onwards, in which he presents a dissertation on making education obligatory in rural Spain, on the need for improvement in the application of The Moyano Law, denouncing what is not working in schools, and what hampers the achievement of the supreme aim of education: combatting illiteracy.

$\mathrm{He}$ is active in the creation of the General Associations of Spanish Primary School Teachers (1881), and a member of the Board of Directors. Later, upon his return to the Peninsula after a period of teaching in Puerto Rico, he is instrumental in the creation of the provincial Associations, as a means of supporting the General Association. He is so conscious of the need for unity in the Teaching profession, "two teachers are worth 25,000" that he creates the magazine El Faro del Magisterio (The Teaching Profession's Lighthouse), as a communication medium of the Provincial Teaching Association.

His ideological coherence in his role leads him to deliver a speech in which he echoes the sentiments of any teacher in any corner of the country, without being intimidated in the slightest by the audience. "Change, change don Juan, a little more Pedagogy and less Worldly-wisdom ..." [3], and he is warned that such comments are not keeping with his personality and his commitment to education. The proposals that he puts forward during thirty years are consistent with the legitimate aspirations of the national Teaching profession. This coherence, and his ardent defence of the demands of teachers, incur the opprobrium of the religious press, which level at him the accusation by which it is easy to disparage someone in Spain at the time: anticatholic. But neither attacks nor disparagement prevent him, on the occasion of the Primary Education Congress (1910) from exposing, defending and at times enduring an audience all too ready to harass him.

\subsection{The National Pedagogical Conference (Madrid 1882)}

The teacher belonging to the Teaching Association which has branches in every province, spearhead the National Pedagogical Congress in 1882, which is organised by the Promotion of the Arts, a body that represents the working classes in Madrid [4]. The interests of the Congress can be classified as follows: the concept of education (its obligatory, free and integrated character); aspects of the training of teachers and the reform of Normal Schools; and issues arising from the experience of school reality [1].

At that time, Macho Moreno is a tenured teacher at the Torrelaguna school, and a member of the Board of the National Teachers' Association (1881). He attends the first Congress with a grant from the Diputación de Madrid [5] the Diputación de Guadalajara and the Torrelaguna Town Council. The National Pedagogical Conference was held from May $28^{\text {th }}$ to June $14^{\text {th }} 1882$, and Macho Moreno participates with a contribution to the debate on Topic VI [6], under the title: "What general reforms are necessary in the way we do primary teacher training so as to improve the material conditions and attract young people who are pursuing other careers?" [4]. The answer he suggests in his contribution is clear and concise: It is the extension of their studies; it is the greatest possible instruction that is communicated to those who devote themselves to it; all the others will flow from it as a necessary consequence [7].

The teachers at the Normal Schools and Public Schools, Primary Education inspectors and the secretaries of the Boards of Public Education are given permission to travel to Madrid to attend the National Pedagogical Congress, under the provisions of the Organic Regulation of April $25^{\text {th }} 1882$. What is worth noting about this regulation is that it decrees the suspension of the classes of the teachers who attend the Congress: Teachers of the Normal Schools and Public Schools of all classes and levels are hereby authorised, during 15 days, to come to this Court in order to attend the said sessions, during which time their respective teaching activities will be suspended [8].

When this Congress is convened, Macho Moreno is a young 34-year-old teacher; however, he already has 15 years' teaching experience. He acquired and enriched his experience in direct contact with pupils in rural towns; in the hard work that this activity involves, he combined with teaching adults and with the organisation of libraries in each of the towns to which he was assigned while eking 
out a living with his paltry earnings, from 375 pesetas at the beginning to 825 pesetas in 1882 . His participation in the National Pedagogical Congress represents the beginning of his active professional involvement in pedagogical debates in Spanish society of the subsequent 30 years. He evinces his respect and apprehension at the prospect of addressing such a distinguished audience drawn from the teaching profession nation-wide, including Claudio Moyano, Ros de Olano, illustrious university chancellors and directors of Normal Schools, among others.

In the congressional debate, the request that the Local Boards be suspended is unanimous. The doubt that is expressed by the Congress is whether the unanimity is for the suspension of the social body, or for the reorganisation of the existing Boards. The view put forward by Macho Moreno in the 1882 National Pedagogical Congress is clear, direct and concise, as he always expresses his views, and coincides with the views of the majority of the teaching body: namely, that the local boards should be suspended, or their composition changed:

"The local Boards, of which all I will say is that they should be totally eradicated, unless they could be made up of individuals who are cultivated and are known by all to love the teaching profession, people with an academic qualification. There is no need for such Boards where this is not possible so that we no longer have to endure seeing them only concerning themselves with education to persecute teachers unfairly, if the latter, in order to preserve their dignity, refuse to comply with the stupid demands of small-minded tyranny." [7]

The law of September $9^{\text {th }} 1857$ [9] decrees, in article 287, that the local public education boards, named by the Governor of the province (article 288), will be made up of: the presiding mayor; a councillor; a member of the clergy, appointed by the corresponding diocese; and two or three fathers. The functions of these local Boards are detailed in article 286 of the law, which amended the fourth section to the effect that instead of reporting to the government or the chancellor, they would report to the provincial Board. These functions are as follows:

To inform the provincial Board in the cases foreseen by this law and any other that might be consulted; 2) To promote improvements and advances in the centres of primary and secondary education; 3) To ensure the proper administration of the funds of the self-same centres of education; and 4) To be accountable to the provincial Board for any deficiency identified in the teaching and the management of the secondary and primary schools placed in their charge.

Essentially, his discrepancies with the local Boards and public Education are twofold. The first is the lack of teachers in the Boards, which results in a feeling of vulnerability among primary school teachers. The second is the evidence that the local authorities are both judge and interested party in the cause. The failures on the part of the Town Councils to fulfil their duty to teachers, and in view of the fact that obligations incurred by law (lodgings, teaching centre, pedagogical material, cleaning material, heating, restocking) are systematically disregarded. Both reasons are sufficient to demand the dissolution of these Boards; or, should this not be possible, their composition would be changed.

Among the many valuable observations, particularly noteworthy are those made by him. The plenary of the Congress votes on each of the topics debated. For topic VI, the following chart shows the conclusions reached by the participants in the Congress. (Table 1):

Table 1. Conclusions for topic VI

\section{Number 29}

Should the salaries of Primary School teachers be less than 4,000 pesetas? (The unanimous answer was no)

\section{Number 30:}

Should the salary for male and female teachers be the same? (Accepted, unanimously)

\section{Number 31:}

Should teachers of both sexes enjoy the same passive rights as other Government employees? (Accepted, unanimously)

\section{Number 32:}

Should they receive gradual salary increments? (Accepted, unanimously)

\section{Number 33:}

Should the Teaching profession be granted its own representation in the Senate? (Accepted, unanimously)

Number 34:

Should the State assume full responsibility for the maintenance of Primary Schools for all classes and at all levels?? (Accepted, unanimously)

Consequently, the above points are incorporated into the conclusions of the Congress, along with 28 points corresponding to the previous topics. The Provincial Board of Public Education in Madrid refers to him as Distinguished Schoolmaster, and one of the candidates for the prizes awarded to teachers in the Public Schools of the province. The Council of the Province of Madrid, under an agreement reached on January $17^{\text {th }} 1884$, awards him the Diploma de Honor y Mérito, as an incentive to encourage him in the exercise of his function and as an honourable precedent for the services corresponding to his career. [10]

\subsection{The National Pedagogical Congress, Albacete (1903)}

The Teaching Profession in Albacete organises the National Pedagogical Congress in this city between September $13^{\text {th }}$ and $21^{\text {st }}$ of 1903 . More than 1,500 members attend, and more than seven thousand teaching professionals are represented [11]. Macho Moreno is one of the participants, among other representatives of the Teaching profession in Alicante. The ministry of Public Education and Fine Arts passes the Organic Regulation of 
$1^{\text {st }}$ September 1903, authorising all civil servants and teachers associated with this ministry to be absent from their residence from September $13^{\text {th }}$ to $20^{\text {th }}$ in order to attend the congress to be held from September $15^{\text {th }}$ to September $20^{\text {th }} 1903$ [12], with a view to enabling teachers to attend the congress [13], without specifying whether or not they are free of their teaching responsibilities or can arrange for substitution. The minutes of the congress are not published, so recourse is had to the information provided by the media of the Teaching profession, especially the magazine La Escuela Moderna, the Heraldo de Madrid, El Magisterio Español (2) and El Magisterio Salmantino [14], all of which contain the texts of the Congress. The speakers are in synch with the pedagogical lines laid down by the Free Institute of Education and the Pedagogical Museum. The interventions are assigned, among others, as follows (Table 2):

Table 2. Speakers and Topics

\begin{tabular}{|l|l|}
\hline \multicolumn{1}{|c|}{ Speaker } & \multicolumn{1}{|c|}{ Topic } \\
\hline $\begin{array}{l}\text { Patrocinio Mareca Guillén } \\
\text { Teacher in Algemesí and } \\
\text { Benicalap }\end{array}$ & $\begin{array}{l}\text { "School walks and excursions. } \\
\text { Their importance and means of } \\
\text { diffusion", along the lines laid } \\
\text { down by Pestalozzi and Fröebel }\end{array}$ \\
\hline $\begin{array}{l}\text { Mariano Munera } \\
\text { Teacher in Corral Rubio }\end{array}$ & "Schools for adults" \\
\hline $\begin{array}{l}\text { Sabas Castrillo Parra } \\
\text { Teacher in Albacete }\end{array}$ & "School buildings" \\
\hline $\begin{array}{l}\text { Antonio Iniesta } \\
\text { Teacher in Alpera }\end{array}$ & "Agricultural experimentation" \\
\hline $\begin{array}{l}\text { Francisco Pérez Cervera } \\
\text { Teacher in Cieza }\end{array}$ & "Graduate schools" \\
\hline $\begin{array}{l}\text { Tomás Pérez Linares } \\
\text { Doctor in Albacete }\end{array}$ & "School hygiene" \\
\hline
\end{tabular}

\subsubsection{Situation in the schools}

The president of the Congress expresses, among other things, the interest of the teaching profession with regard to the conference topics, no advantages are being requested for the teachers; all the improvements are for the school. Education is the task of the whole community [14]. When it is the turn of the minister Bugallal, he expressed his satisfaction that the Nation was rising out of the disasters of the past [15]. The minister addresses the problem of education, of teaching and the Teaching profession, acknowledging that ministerial policies have neglected the Primary School, as evidenced by the fact that the corresponding classrooms in the Normal Schools are virtually empty. The demands, which made my Macho Moreno 20 years earlier, have not been adequately heeded.

"I regret the current state of the Normal Schools, which have almost been deserted in recent years, making it difficult to provide teachers for our schools. Teachers deserve the greatest attention that we can pay to them on account of the history of grievance and bitterness that they have suffered. There was a time when preferential treatment was afforded to universities; with the rise of the middle classes, attention has been turned to the secondary school; now that the people are governed by democratic laws, and anyone can rise to the highest place by virtue of their humanity, we must turn our attention to primary education, to instruct our children and equip them to fulfil their duty. It is not enough to teach Reading and writing, what is needed is an integrated education. If we condemn our teachers to such a precarious condition, how can we expect them to work in the school with enthusiasm? The government is concerned about primary education and wishes to hear the opinions of the teachers. I promise to study the conclusions that are voted and to do what I can to ensure that they are implemented." [14]

Those who campaign for greater involvement of teachers from the provinces in cooperative associations draw attention to the democratisation of society and the organisation of social classes into defenders and disseminators of their interests:

"We live in a regime governed by opinion, and now it is not only the ministers and the Court that rule us; now we are ruled by the social classes organised in a modern way, propagators of their needs, disseminators of their interests, who speak out and shout, who conquer public opinion and make it their ally." [16]

Activists striving to improve the Teaching profession at the beginning of the $20^{\text {th }}$ century conceive of the mobilisation of the sector as the force which will change its status, and society itself; to this end, nothing is better than broadcasting its concerns. This vision corresponds to the "social media" of today, which generate such renewal by their way of "speaking out and shouting".

"The Congress is a great meeting of teachers and professors from different Spanish regions, which will convey to the powers that be the needs of the school, and the reforms that must be undertaken in the primary school so that it can become what it must be, the fundamental basis of the nation's culture and prosperity." [11]

\subsubsection{Graded school}

The Congress deals with issues concerning the Graded School. On behalf of the Madrid press, Jiménez Moya offers his support for the establishment of graded schools of the kind proposed by Pérez Cervera; Ruiz Jimenez addresses the plenary, and receives the approval of the Congress for the reforms introduced in schools in Madrid (school walks and excursions); the division of pupils into grades, the single class; the playing fields and agricultural experimentation; asylum schools and schools for adults); a teacher in Tobarra, Navarro Rubio to request the elimination of the public school local boards, and of the kind of exams that are being done at this time; besides, he asks for the establishment of the single class, the creation of school canteens and the reorganisation of the inspectorship [17].

In his intervention, Macho Moreno speaks up for Noya 
Viqueira's pedagogical museum, which boasts a didactic collection of fossils, metals, precious stones and plant-life from the whole peninsula:

"It is divided into several sections and contains various collections of fossils, metals, precious stones and plant-life from different Spanish provinces, geological maps, geographical and historical atlases, devices to help children graphically learn subjects related to geometry, anatomy, physics and astronomy. It also contains tools and artefacts of agricultural machinery and the textile industry, such as silk and lace, and the fabrication of soap, photography and other industries that facilitate, and accustom children to, manual tasks; as well as exhibiting pedagogical advances in Italy and Sweden". [18]

The requests of the Teaching profession are for the regeneration of primary education, and of the school, in which all the sectors of society must participate, because education is for everyone. The school is compared to the People's University: in the words of the minister, Today the people are governed by democratic laws, and any man can now aspire to the most eminent positions, only because he is a man. We must turn our eyes to the school to educate the child and equip him or her to fulfil their duties [14]. The exhibition is valid for women, many of whom participate actively in the Congress, and in the educational life of the country.

Macho Moreno participates in a Teachers' Committee, which interviews the minister of Public Education, to raise urgent issues relating to the education sector: equipping educational centres better; raising teachers' salaries; reinforcing school inspections; making teaching more widely available and guaranteeing this by increasing the education budget $[19,20]$.

Throughout the Congress, numerous aspirations are expressed, and the conclusions are aimed at high ideals, because the needs and concerns expressed reflect such ideals. The main conclusions of the 1903 National Pedagogical Congress that are approved are: the need to create school walks, camps and excursions; the construction of school buildings that are in keeping with the demands of modern Pedagogy; the creation of canteens in Schools; the implantation of graded schools throughout Spain; and securing, as soon as possible, the creation of practical workshops in schools. [21,22].

They could not fail to mention the Teaching professions perennial aspirations either: the elimination of the local Education Boards and the official school exams; that the State would assume responsibility for the maintenance and for the payment of its financial obligations to primary education; that the minimum wage for teachers should be 750 pesetas per year; and the allocation of material in proportion to the number of children attending the schools $[22,21]$.

One of the novelties in the conclusions of the Congress is the creation of a National College of Orphans of the
Teaching profession. In the absence of the national protection system, the professional fraternities demand and create assistance for the orphans, who will otherwise be unprotected. Macho Moreno practises and/or completes the conclusions of the 1903 National Pedagogical Congress, which demonstrates the extent to which he remains at the cutting edge of contemporary pedagogy.

\subsection{The National Pedagogical Congress, Zaragoza (1908)}

His personal and professional energy leads Macho to participate in pedagogy-related events and in social movements aimed at advocating for the teaching profession. In 1908 the national pedagogical congress is held in Zaragoza, from October $21^{\text {st }}$ to $25^{\text {th }}$, and 276 people sign up for it [1]. Macho Moreno, now more mature than at the time of the 1882 Congress, agrees to take part. At 60 years old, with an extensive pedagogical curriculum and with the authority accorded by the directorship of the Normal School of Alicante, he no longer feels intimidated in the slightest by the responsibility of the occasion, or by the audience, though he is aware that his words and proposals will be scrutinised by the Teaching media and by his peers in the profession.

The Congress addresses the concerns of the Teaching profession, but it does not tackle the most burning issues, such as the secularity and state-regulated character of education. It is possibly the absence of these issues that accounts for the indifference of the Free Institution of Teaching towards the Congress.

Participants in the Congress are potentially public and private teachers in any branch of the Teaching profession; civil servants and faculty members whose jobs are related to the said profession; the writers and promoters of pedagogical material; anyone with an interest in general culture. Attendees are required to complete an application form and pay a fee of 5 pesetas.

Five speeches are delivered at the National Pedagogical Congress, 1910 on the subject of the functions and organisation of the school; the reform of the Normal Schools and teacher training; and the institutions of promotion and control, that is to say, inspection [1]. Particularly noteworthy are the third one on influences on teacher training with a view to enhancing the teacher's performance of their duties; and the one focusing on inspection as a means of incentivising teachers. Macho Moreno's speech is about: "Having a decisive influence on the training of the teacher for the best results of his or her transcendental mission. What is such training like in Spain, and what should it be like? Uniting studies and genuine professional centres where they can be verified",

The Congress is a medium for the exposition of papers, which will give rise to sensible discussions and reasoned polemics, to be presented to the powers-that-be in the form of conclusions, with a view to their being translated into 
legislation, in the words of Macho Moreno. Essentially, this describes the format of the Congress. The spokesperson from the graded school, Marti Alpera, takes educational action one step further when he demands an organisational change in public education: from ungraded to graded; from an unlimited number of pupils to a maximum of 40 per teacher; State intervention to tackle the problem of sectarian and intransigent entities. Among the resolutions of the second topic, approved by the Congress, the second (hygienic and pedagogical conditions) and third (only the graded model is acceptable) are particularly worth highlighting.

As regards the third topic of this Congress, Decisive influence in the training of teachers to secure the best results of their transcendental mission, the steering Committee in the session held on June $9^{\text {th }}$, agrees, among other things, to invite Macho Moreno, among other distinguished experts, to give lectures on issues related to education, in order to explore the third topic, which is presented on October $23^{\text {rd }} 1908$ [23]. The magazine El Faro del Magisterio devotes an entire issue, in a bindable format, to publishing the paper presented by its learned director [3].

The subject of his paper was the professional training of teachers and the means that must be used so that it can achieve its aims [24] and it is divided into three main points of reference. In the first place, the training of teachers is important because teachers are made, and conditions in which they are made must be good, so that they can become as useful as possible to the education of the people [25]; these conditions include character, knowledge and special vocation, alongside others that can only be acquired in the Normal Schools [25] He assumes the era of the "Mr Windbag", the teacher who pontificates endlessly but knows next to nothing, to have become a thing of the past, and warns about the office technocrats, who often act like the instructor of the young army recruits, sending them over the top as cannon fodder [25].

He demands resources for teachers, like those readily available abroad (a school building, material, a limited number of pupils, punctual attendance at class, salary, etc.); and as regards wages, he denounces the fact that there are many teachers still earning 250,300, 350 or 400 pesetas [26]. In teacher training he denounces the dereliction of duty on the part of the ministers with regard to the reforms of the Normal Schools, in particular the elimination of calligraphy and reading from the syllabus; and the disappearance of the Normal Certificate in 1901. As regards the second point, teacher training in Spain, Macho Moreno's exposition is hard-hitting, to the point where he even asks the audience if he can speak frankly or will have to resort to hypocrisy. In his view, teacher training in Spain was extremely deficient, erroneous, and mediocre; consequently, the Teaching profession lacks quality [25].

The preparation of teachers is incomplete in the Normal
Schools (teaching methods, theory) and in the case of free education, which is devoid of teaching practice. Therefore, to tackle this deficiency, he proposes reforming the Normal Schools and eliminating free education for a Teaching qualification. In his third point, he defends the validity of the Normal Schools for Teachers and unites academic disciplines. To the outrage of some, due to the system he confronting, he criticises the allowances provided for study outside Spain, and proposes the creation and organisation of a school of international pedagogical studies, as an integral part of the Central Normal Schools. In his conclusion, he urges Everything mandated to date must be dispensed with as worn out and useless, let us throw it all out. What use is it? Instead, let us open broad pathways to progress, to that which moves us forward, to what looks ahead in order to improve the future. Let us not regress! [25].

During the exposition, he displays his extensive knowledge of educational legislation, and a fiercely combative, feisty spirit, and, unusually for his age and his high-ranking position as director of the Normal School, remains determinedly uncompromising, a spirit which was born of and rooted in the heat of real experience.

The conclusions safeguard the material interests of the Teaching profession, in opposing all interference in the Normal School. The minutes of the session show that Macho Moreno's exposition explores with great thoroughness and competence each of the points comprised by the topic.

The main conclusions accepted by the Congress are: reaffirming the meaning of primary education; the integral character of the education of the whole person; the teacher as the main agent of education; instruction is the natural medium of education; the pedagogical and social value of the school; the need for graded schooling; the pedagogical use of kindergartens [1].

\subsection{The Barcelona Primary Education Congress (1909)}

The public teachers of Barcelona organise the Primary Education Congress, to be held from December $26^{\text {th }}$ to January $2^{\text {nd }}$ of 1910 , which promises to be a true pedagogical spectacle. The topics to be debated are burning issues in the teaching profession; and the speakers are distinguished teachers, lecturers at the normal schools, architects, doctors, publicists, all of whom are of renowned competence and unadulterated love for teaching [26]. Macho Moreno is a speaker on one of the topics of the second section [27].

The set of questions on the topics approved by the steering committee is: Questions concerning doctrine or questions of a general pedagogical nature; The Second section: Organisation of the teaching body; The Third section: Hygiene, buildings and school administration; and the fourth section: Organisation and functioning of primary schools in their different classes and grades 
$[28,29]$.

The equal attendance of men and women and the significant representation of religious orders. The Congress is born with two different souls: on the one hand, liberals, radicals, progressives; on the other hand, reactionaries, Carlists, Catholics. On the first day of the Congress, pamphlets are distributed accusing several of the speakers of being enemies of God and of the Catholic school; two diametrically opposed tendencies being made manifest from the outset [30]. Only four months have passed since The Tragic Week; and a mere seventy-two days since the creator of the journal The Modern School was shot in the castle of Montjuic. These two facts, combined with the conflicting positions representing renewal and reaction, and the very present memory of the loss of the Spanish colonies, play a fundamental role in radicalising the participants in the Congress.

The accidental mayor of Barcelona presides over the inauguration of the Congress. Other speakers included Macho Moreno from The Normal School of Alicante. The lecture entrusted to Macho Moreno, The autonomy of primary education. Its direct intervention in the sector's affairs, corresponds to the second section. The second day could not have got off to a worse start, as Ramón Clausolles tries to propose a change in the programme for the day, which sparks such an outcry that he has to stand down. The next lecture to be given is on the subject Autonomy of the Teaching profession, in which the speaker unpacks his proposals for absolute autonomy for those who understand and aspire to full autonomy, and makes the following suggestions in his conclusions:

"The enjoyment of absolute, full autonomy is no longer only a matter of methods, procedures and ways of teaching, but also concerns administration and the application of official laws and provisions. As a result of this new organisation, primary education should therefore operate under the direction and supervision of its own, essentially technical agencies, with no interference from extraneous elements of any kind". [31]

As soon as he (Macho Moreno) utters the words "with no interference" the most reactionary section feels that their control over the privileges corresponding to the private, confessional school is being threatened. Once again, chaos descends on the lecture hall, to the point where the police have to intervene. Each of the subsequent expositions triggers renewed confrontation between the two groups. The intransigent sector, the private, confessional school, considers teaching inspection to be the exclusive prerogative of the Church, as it was during the first half of the $19^{\text {th }}$ century. The Catholic attendees present and approve, in response to the opinion expressed by the speaker, [32] the following amendment: Without detriment to the right of the ecclesiastical authority in all matters relating to the teaching of Religion and Morality [33].

It is noteworthy that Juan Moreno is proposing a complete overhaul of the organisation of primary education, always proclaiming the autonomy of the Teaching profession in the teeth of what he regards as the intrusion by other levels of administration and teaching into the teachers' territory. Needless to say, the most entrenched sectors of society, which have always controlled education, vent their fury against this speaker, well-known for his ideas and for his battles, and against his conclusions. When it came to voting on the conclusions, the majority of the participants registered, with the aim of dominating and winning the vote, without attending to the criteria or the debates.

The speaker acts as if he were a Trade Union delegate for the Teaching profession: he even twice invokes the concept of class, defined by the RAE (the Royal Academy of the Spanish Language), in a second meaning of the term, as $A$ collection of people of the same level, quality or occupation. That is how he views the Teaching profession, with its vision of a set of common professional and social interests. He says an important class within the State; or autonomy of the class [34].

The conclusions of the speaker accepted by the Congress are those that pose no threat to the established powers that have endured during the previous century. Nevertheless, the core conclusions are rejected; only those that concern form rather than the essential content are passed. It could not have been otherwise after he provoked the rage of the catholic confessional school with his arguments aimed at regenerating primary education. It is more likely that, if the teachers who dissented from the confessional lobby had not left the plenary of the Congress, the outcome of the voting might have been different. Nevertheless, the war of attrition being waged by Macho Moreno and those in the Teaching profession who are convinced of the need for renewal ends up bearing fruit, not least among the students of the Normal School of Alicante who arrange for teachers from the province of Alicante to be represented on the General Workers' Union.

\subsection{The General Board of Teaching and Education (1910)}

On September 22nd, 1910, the Royal Decree of September $18^{\text {th }}$ is published [35], convening the General Assembly of Teaching and Education, to discuss and put forward the reforms that are necessary or convenient for national culture. This call is important and distinctive in that it is the first to be organised by the ministry of Public Education and Fine Arts through the Gaceta magazine, the previous such events having been convened by professional bodies, with ministerial support.

The Board of teachers at the Normal School of Teachers in Alicante, of October $31^{\text {st }} 1910$, agrees that the Committee of this School should be made up of Macho Moreno (the director of the school and the president of the committee), and others. The attitude of the director is 
coherent, as at the Assembly different points of view, ideas, from the teaching fraternity are expressed, but he does not participate on his own behalf; for that reason, a commission of experts is created, with a view to elaborating the main approaches, which, after being discussed and approved in a staff meeting, will be presented to the Assembly. The Congress is convened barely nine months after the end of the Primary Education Congress in Barcelona. On that occasion, the teachers at confessional schools were mobilised, responding to a call from the upper echelons of confessional education.

The Teaching profession has denounced countless problems. As Macho Moreno has pointed out in many congresses and assemblies, which have not been solved, nor is there the slightest hint of a solution on the horizon: low salaries. He demanded a salary of 1000 pesetas in 1882 , and now they get 750 pesetas; most of the buildings that are fit for purpose, hygienic spaces would not even be adequate to keep animals in, as they have no light, no ventilation, not enough space to move in; a budget for pedagogical and scientific material, whereas the current budget is not even sufficient for paper, pens and ink; frequent skills-related inspections, no to local Boards, the single-greatest impediment for enhancing the school, as Moreno denounced in Barcelona, in a proposal which was rejected by 280 votes, because confessional schools do not have to suffer these problems [36,37]

In 1910 the press is aware of the ministerial crisis, which ends with three ministers having to resign, including the minister of Education and Fine Arts. The year of 1911 began with the minister of Public Education pursuing new objectives and new programmes; and the decapitation of the Steering Committee of the well-intentioned General Assembly of Teaching and Education, which aims to discuss and put forward the reforms that were essential or convenient for the culture of the nation [38].

On previous occasions, the reform and modernisation of public education, in terms of its organisation, structures, systems and programmes, loses its project for a better future; the public school will remain in a precarious state, with no budget, and no enthusiasm; and the Teaching profession falls short of its dignity.

\section{Conclusions}

The aim of this research was to show how the use of pedagogical conferences during 1882-1908 and provide a secure and yet inspiring springboard for schoolteachers to implement innovative ideas at a time when the scarcity of sources was the norm. Through Macho Moreno's eyes we witnessed some of the struggle and how this leading scholar played a decisive role in such conferences making important headway to disseminating knowledge, fighting to get better conditions for teachers and helping to overcome illiteracy in Spain.

\section{REFERENCES}

[1] M.R. Domínguez. El perfeccionamiento de los maestros en las primeras décadas del siglo XX: Congresos, conferencias, certámenes. (The training of primary school teachers for the 20th century: Congresses conferences, meetings) Revista Interuniversitaria Formación Profesional. Universidad de Murcia, 1989.

[2] L, Batanaz. Los congresos pedagógicos: una plataforma para la renovación educativa. Vida Escolar, 220-221: pp.119-123, 1982.

[3] El Magisterio Español, November 21st, 258: pp. 19, 1908.

[4] La Paz del Magisterio. January 25th, 3, pp.3, 1881.

[5] Gaceta de Madrid. August 13th, 225, pp. 502, 1882.

[6] HSM, Merits and special services, 2, pp. 10, 1882.

[7] J, Macho. Congreso Nacional Pedagógico, pp. 263, 1882.

[8] Gaceta de Madrid. May 10th,130, pp. 418, 1882.

[9] Gaceta de Madrid. September 10th, 1710, pp. 1, 1857.

[10] HSM, Prizes, honours and decorations, 3, pp. 3, 1886.

[11] El Magisterio Español. September 19th, 2,719, pp. 1, 1903.

[12] Gaceta de Madrid. September 3th, 246, pp. 2201, 1903.

[13] El Liberal. September 10th, 6648, pp. 3, 1903.

[14] El Magisterio Salmantino. September 25th, 28, pp. 1, 1903.

[15] Heraldo de Madrid. September 18th, 4686, pp. 3, 1903.

[16] El Magisterio Español. September 12th, 2717, pp. 1-2, 1903.

[17] El Magisterio Español. September 30th, 2722, pp. 3, 1903.

[18] D, Comas. El IV Centenario de la fundación de la Universidad de Valencia. Universitat de València. Spain, 2002.

[19] El Faro del Magisterio. August 12th, 52, pp. 2, 1903.

[20] F, Larrosa, L, \& Maldonado. Las escuelas Normales de Alicante: conservadurismo y renovación entre 1844 y 1931. Universidad de Alicante, 2012.

[21] La Vanguardia. September 26th, 8828, pp. 6, 1903.

[22] El Magisterio Salmantino. September 27th, 29, pp. 1, 1903

[23] La escuela moderna. November 1st, 207, pp. 831-832, 1908.

[24] National Pedagogical Congress, pp. 214, 1908.

[25] Congreso Nacional Pedagógico Zaragoza, pp. 120, 1908.

[26] El Pueblo. November 25th, 6356, pp. 2, 1909.

[27] Diario de Alicante. October 2nd, 794, pp. 2, 1909.

[28] La Orientación. November 19th, 132, pp. 2-3, 1909.

[29] El Magisterio Balear. November 27th, 47, pp. 2, 1909. 
[30] La Vanguardia. December 28th, 13303, pp. 2, 1909.

[31] El Pueblo. December 30th, 6391, pp. 3, 1909.

[32] La Cruz. December 31st, 2481, pp. 1, 1909.

[33] Las Provincias. Dececember 30th, 15.809, pp.3, 1909.

[34] J. Macho. Congreso de Primera Enseñanza, pp. 147-149,
1911

[35] Gaceta de Madrid. September 22th, 265, pp. 829-831, 1910.

[36] El Porvenir segoviano. October 4th, 3566, pp. 2, 1910.

[37] El Magisterio Español. October 4th, 3.493, pp. 5-6, 1910.

[38] Gaceta de Madrid. September 22th, 265, pp. 829-831, 1910 